\title{
Embracing the Spiral:
}

\section{An Action Research Assessment of a Library-Honors First Year Collaboration}

Sarah LeMire, Thomas D. Sullivan, and Jonathan Kotinek

\begin{abstract}
Librarians often use assessment methodologies to evaluate the efficacy and impact of their information literacy instruction sessions and programs. In this article, researchers use an action research methodology to explore the effect of information literacy instruction on first-year honors student assignments. The researchers explain how they implemented multiple cycles of planning, acting, observing, and reflecting in order to better understand student needs, increase the impact of library instruction, and communicate that impact to library and external stakeholders. Robust and cyclical assessment gave librarians and their strategic partners the opportunity to make iterative improvements to instruction, address issues of overconfidence in students, and make the case for additional information literacy instructional opportunities for honors students.
\end{abstract}

\section{Keywords}

Information literacy; Library instruction; Honors students; Action research; Assessment

\section{Introduction}

Library instruction in first-year courses is common practice in academic libraries. Many libraries have robust, scaffolded information literacy programs that are embedded within their campus first-year experience programs or general curriculum. In addition, many libraries have collaborated with strategic campus partners to develop information literacy interventions for specific populations on campus, including specific departments or majors, underserved populations, or honors programs.

Despite the wealth of knowledge and approaches in the literature, librarians continue to struggle to determine whether their instructional efforts are successful. Is a lesson plan that was popular a couple of years ago still engaging students? Would an activity that worked well at another institution translate to a different campus environment? Are students learning what they need in order to be successful in college, or just to be successful in their current assignment? These questions and more continue to be asked by libraries and librarians across the country. Assessment using an action research model is one way to begin to answer these questions.

At the Texas A\&M University Libraries, librarians were approached to partner with the University Honors Program to improve first-year honors students' information literacy skills and knowledge. A critical 
element of the collaboration would be assessment of student learning, which was intended to ensure the impact of library instruction to honors students.

The research questions for the Honors Housing Community assessment project included the following:

1. What information literacy skills and knowledge gaps do first-year honors students exhibit at Texas A\&M University?

2. Can library instruction sessions improve first-year honors students' ability to demonstrate common information literacy skills such as source evaluation and source attribution?

3. Which methods of information literacy instruction have the largest impact on first-year honors students' ability to demonstrate common information literacy skills?

In order to address these questions, the researchers designed an assessment based upon an action research model of iterative reflection and improvement.

\section{Institutional Background}

Texas A\&M University is a very large university serving more than 60,000 students in College Station, Texas. Of these $60,000+$ students, approximately 12,000 are first-year students. The University currently does not offer a unified first-year experience program to engage first-year students. Instead, students can choose to participate in a wide variety of learning communities, living/learning communities, and other first-year experience programs across campus. One of these living/learning communities is the Honors Housing Community $(\mathrm{HHC})$ program, which is the first-year component of the University Honors Program (UHP).

The UHP is part of LAUNCH, a campus unit that coordinates high-impact learning practices such as learning communities, capstones, and undergraduate research across campus. The UHP is a four-year program that kicks off with a robust first-year experience. During that first year, honors students live oncampus and participate in a zero-credit, one-hour, weekly class led by a sophomore peer advisor. These weekly meetings focus not only on general campus resources, but are aimed at engaging students personally, professionally, and intellectually through reflection on long-term goals and how these are tied to personal values.

Since the 2014-2015 academic year, one of the cornerstones of the HHC program has been the Bridge Essay. The Bridge Essay is the assignment students complete as a bridge between the Fall and Spring semesters each year. After a pilot implementation of the Bridge Essay, the UHP coordinators reached out to the University Libraries for help with the Bridge Essay assignment. Particularly, the UHP coordinators were interested in improving the quality of the feedback that $\mathrm{HHC}$ students received in response to their Bridge Essays and in assessing the impact of direct student instruction.

The University Libraries' First Year Experience Librarian was enthusiastic about the opportunity to develop an information literacy partnership with the UHP. However, as a large-scale collaboration, assessment would need to be a critical element not only as good instructional practice, but also to 
determine the sustainability of the UHP-Libraries collaboration. Assessment could help demonstrate the impact of the collaboration to subject liaisons and other stakeholders inside and outside the Libraries.

\section{Literature Review}

Librarians frequently provide information literacy instruction to special student populations. Librarians have explored the value of library instruction for populations such as transfer students (Robison, 2017) and international students (Avery, 2017). Another unique population explored in the literature on information literacy instruction is honors students. For over 30 years, librarians have been writing about the information literacy needs of honors students. In 1984, Yee called for a "close alliance" between libraries and campus honors programs, a call echoed more recently by Johnson (2012), who developed a long-term collaborative relationship between the two campus units. Librarians are working with honors students in a variety of disciplines, rhetoric, and thesis classes (Kraemer, 2007); biology (Johnson, Anelli, Galbraith, \& Green, 2011); and chemistry (Ferrer-Vinent, Bruehl, Pan, \& Jones, 2015), but in common they share the goal of improving students' facility with, and understanding of, scholarly literature. This is because, while librarians such as Wilson \& Mulcahy (1987, p. 700) have identified honors students as "potential scholars at the very outset of their careers," they have also noted that honors students' research skills are not superior to non-honors students, a view seconded by Kraemer (2007).

To measure the impact of library resources and services and demonstrate value to stakeholders, librarians have turned to assessment. Librarians use a variety of methodologies to assess the effectiveness of information literacy instruction. Erlinger (2018) found in the literature seven methods used to measure effectiveness of information literacy instruction; rubrics were used in 25 percent of those cases. Oakleaf (2008) highlighted several benefits of using rubrics for both students and librarians, including: "(1) students understand the expectations of their instructors, (2) students are empowered to meet standards, (3) students receive direct feedback about current and future learning, and (4) student self-evaluation is facilitated. For librarians engaged in instructional assessment, rubric advantages include: (1) agreed upon values, (2) reliable scoring of student work, (3) detailed result data, (4) a focus on standards-based education, (5) evaluation of student learning across time or multiple programs, and (6) cost" (p. 245). The drawbacks of using rubrics are clearly established in the literature; for example, Oakleaf $(2008,2009 b)$ noted that common limitations in using rubrics are time and quality of construction. However, many librarians report that rubrics helped them assess student application of information literacy concepts and the effectiveness of information literacy instruction. Librarians at Virginia Commonwealth University detailed how they used a rubric-based assessment to understand student learning in a sophomore-level research and writing class and to subsequently make adjustments to library lesson plans (Gariepy, Stout, and Hodge, 2016). Kiel, Burclaff, and Johnson (2015) describe the impacts of their multi-year, mixed-methods, assessment project that evaluated the information literacy skills of students in two undergraduate courses. Based upon this assessment, which included a rubric, curricular changes were made in both studied courses. And librarians at Champlain College used a rubric and a checklist to evaluate annotated bibliographies from students in a common first-year course, with findings that were incorporated into a redesign of library lesson plans for that course (Carbery \& Leahy, 2015). These are just a few of the myriad studies in the literature detailing how librarians have used 
rubric-based assessments to better understand gaps in student information literacy skills and close the loop by making changes to lesson plans.

Although many librarians report closing the loop on their assessment, fewer articles detail ongoing, iterative assessment for curricular improvement. Oakleaf (2009a) used a rubric-based assessment as a case study to demonstrate how iterative assessment can be used to improve both student outcomes and librarian teaching. Action research is another method that librarians have been using to conduct ongoing, cyclical assessment of information literacy in order to inform practice. Action research is a methodology commonly used in teaching and learning. It is a practitioner-focused research method which encourages instructors to investigate and reflect upon their own teaching. Norton (2009) explained that "the purpose of pedagogical action research is to systematically investigate one's own teaching/learning facilitation practice with the dual aim of modifying practice and contributing to theoretical knowledge" (p. xvi). In recent years, action research has become increasingly popular in libraries, and particularly among instruction librarians, who have used action research to assess and revise information literacy curricula. For example, librarians at Mount Saint Vincent University used action research to better understand graduate students' perceptions of two different information literacy instruction delivery methods, a tutorial and a one-shot session, and identified areas for improving engagement with tutorials based upon their findings (Harkins, Rodrigues, and Orlov, 2011). Squibb and Mikkelsen (2016) used action research to assess the impact of a curriculum revision that embedded information literacy in a first-year composition course. Margolin, Brown, and Ward (2018) described using action research-based feedback from students and instruction librarians to make small, iterative changes to a comic-centered lesson plan for incoming first-year students. And Insua, Lantz, and Armstrong (2018) conducted an action research study of student research journals, which provided the researchers with new ideas for collaboration and classroom activities to support student learning.

While the library literature indicates that librarians are increasingly embracing action research as a method for making changes based upon information literacy assessment, there are few examples of this iterative assessment and change in action. This article fills a gap in the literature by detailing how librarians can use action research over multiple cycles to make and assess the impact of iterative improvements to library instruction.

\section{Methodology}

This study employs action research to evaluate the information literacy skills of first-year honors students, develop and implement information literacy instruction to support first-year honors students, and assess the efficacy of that instruction. Action research is inherently an iterative and recursive process, often described in terms of the action research spiral with the following steps (Kemmis, McTaggart, and Nixon, 2014, p. 18):

- Planning a change

- Acting and observing the process and consequences of the change

- Reflecting on these processes and consequences, and then 
- Re-planning

- Acting and observing

- Reflecting, and so on...

The data collected in this study was gathered as part of an ongoing and programmatic library assessment effort and in order to provide feedback to HHC students, but the researchers opted to also review and report this data through an action research lens. To that end, the researchers sought and received Institutional Review Board permission to analyze programmatic assessment data for HHC students from the 2015-2016 academic year and, subsequently, the 2016-2017 academic year.

The data set for this study included all of the feedback librarians provided to HHC students as part of the Bridge Essay evaluation. Librarians scored essays using a rubric which included space for librarian comments to students. The researchers aggregated the data into a spreadsheet format and added a column to identify whether the student had been present for a library session. The lead researcher coded the librarian feedback into categories. All personally identifiable student information was removed from the data set prior to analysis. The researchers opted to focus on the qualitative librarian feedback in order to better understand the problem areas that librarians were pointing out to HHC students.

\section{Planning a Change (2015-2016)}

The first step to the action research process is planning a change. In spring 2015 , the UHP and the University Libraries' Learning and Outreach personnel met to discuss the upcoming 2015-2016 academic year and develop a plan for an information literacy collaboration. This session was constructed around HHC's new assignment, the Bridge Essay.

As a zero-credit course led by sophomore peer advisors, the HHC course required few out of class assignments. However, in order to pass the course, all first-year honors students had to complete the Bridge Essay assignment during winter break, as the assignment was intended to help bridge the gap between the two semesters. Students were to identify an issue in their chosen field of study, such as ethical dilemmas in health care, high rates of post-traumatic stress disorder in the military, or barriers to implementing autonomous vehicles. Ideally, students might discover an issue that they could choose to study throughout their undergraduate careers. Students would be required to explore this issue in the literature and write an essay discussing the issue and how it connected to their educational or career goals. Based upon these expectations, librarians designed a lesson plan focused on evaluating, finding, and citing sources.

The Libraries/UHP partnership would support students as they prepared for the Bridge Essay assignment. Although students would not receive a letter grade for the assignment, librarians would provide feedback to each student about their completed assignment.

The Libraries/UHP collaboration was framed around the following goals:

1) To better support the information literacy needs of honors first-year students 
2) To garner a better understanding of the information literacy knowledge and skills of a highachieving group of first-year students from a variety of disciplines

3) To improve the quality of feedback provided in response to the Honors Bridge Essays

To meet these goals, librarians and UHP coordinators crafted two-stage collaboration. First, librarians would meet with each $\mathrm{HHC}$ section for an information literacy session before the winter break in order to help students prepare for the Bridge Essay assignment. Second, the collaboration would conclude with librarians evaluating each completed Bridge Essay assignment using a rubric and providing feedback to the honors students on their work.

\section{Acting and Observing}

\section{Information Literacy Sessions}

The second step of the action research process was to act upon the plan and observe that action. Accordingly, librarians developed and implemented a lesson plan in the form of an alignment grid for the information literacy sessions (see Appendix A). For this information literacy lesson plan, librarians chose to focus on the learning outcomes below. The learning outcomes were intentionally broad in coverage, as librarians were still learning about the specific needs of this group and the Bridge Essay assignment.

At the end of this session, students will be able to:

1. Identify characteristics of a scholarly article

2. Apply the $5 \mathrm{Ws}$ and $\mathrm{H}$ model to identify and articulate strengths and weaknesses in a variety of web content types

3. Articulate their chosen topic in the form of appropriate search terms

4. Find and select a source on their chosen topic

5. Identify citation information on a given journal article.

In November 2015, five librarians from two library departments taught information literacy sessions for each of the HHC sections. Librarians held 23 sessions for $40 \mathrm{HHC}$ sections. Each HHC section had between 10 and 12 students, so to maximize use of resources, some concurrent sections were combined into a single information literacy session. During these 23 sessions, librarians taught 230 students. Only 12 students did not attend any of the information literacy sessions. In addition to the in-person library session, librarians created a citation tutorial that was made available to all students ahead of the library session and throughout the course of the assignment.

\section{Bridge Essay Feedback}

In January 2016, students turned their completed bridge essays to the HHC program. UHP coordinators shared the essays with the First Year Experience Librarian, who was responsible for coordinating librarian feedback for each essay. The First Year Experience Librarian replaced student names and identifiers with a unique code indicating the student's college and major. Seventeen librarians from six library departments volunteered to participate in a grading session on February 17 and 18, 2016. The 
grading session began with norming. Using a rubric (Appendix B), each librarian was asked to score the same essay independently, and then the group came together to discuss the assigned scores and come to an agreement on areas where they differed. They then scored a second essay independently and came together a second time to ensure that scores were now similar.

After norming was complete, librarians scored the bridge essays. Each essay was evaluated by two different librarians. Essays were divided by major so students could receive feedback from at least one librarian with relevant subject matter expertise. Where librarian scores differed, a third librarian would score that category to break the tie. At the end of the scoring, rubrics and feedback were typed up into a clean rubric sheet and returned to students. Content from the rubric sheets was also added to a spreadsheet for programmatic assessment and subsequent analysis.

Once all of the rubric sheets were added to the spreadsheet, one of the researchers reviewed the librarian comments. The researchers coded the comments into 14 categories (Table 1). These categories were examined in relation to the topics covered in the information literacy sessions.

\begin{tabular}{|c|c|c|}
\hline Comment Categories & $\begin{array}{l}\text { Attended } \\
n=230\end{array}$ & $\begin{array}{l}\text { Did Not Attend } \\
n=12\end{array}$ \\
\hline Citation errors & 122 & 2 \\
\hline Needs scholarly sources & 83 & 0 \\
\hline Missing in-text citations & 68 & 5 \\
\hline Connection of goals to issues & 62 & 2 \\
\hline Incorrect citation style & 41 & 2 \\
\hline $\begin{array}{l}\text { Scholarly/popular (i.e. misidentification of } \\
\text { source type) }\end{array}$ & 32 & 0 \\
\hline Identification of goals & 23 & 0 \\
\hline Substantiation/attribution issues & 21 & 1 \\
\hline Writing errors & 17 & 0 \\
\hline Needs popular sources & 10 & 0 \\
\hline Real-world issue & 8 & 0 \\
\hline Insufficient sources & 7 & 0 \\
\hline Assignment format & 6 & 0 \\
\hline
\end{tabular}


Source selection (i.e. source quality issues) $\quad 5 \quad 0$

Table 1: Coded Librarian Comments (2015-2016)

\section{Reflecting}

The third step of the action research process was reflecting on the earlier stages. Analyzing the assessment data revealed several findings that librarians and UHP coordinators found enlightening. First, for students who attended the information literacy session, the most frequent comment category was citation errors. This was a concerning finding for librarians, as they had both created a citation tutorial for students and had also covered citation during the information literacy sessions. In addition to citation formatting errors, students also struggled with other citation-related tasks. Librarians frequently commented on the need to cite sources in-text, to attribute claims, and to choose an appropriate citation style for their major. These comments revealed a gap in the information literacy lesson plan. While citation was covered both in the tutorial and classroom information literacy session, both aspects focused primarily on correctly formatting citations in the reference list. While the librarian comments revealed that this was indeed a problem area, they also revealed that additional attention needed to be paid to the ethics of information use, including why and how to cite sources within the text.

After citation formatting errors, the most common issue that librarians mentioned was the lack of scholarly sources. Although librarians discussed how to find scholarly sources in the information literacy sessions, their comments revealed over 80 mentions of students failing to include the requisite number of scholarly sources. This finding was particularly of interest to librarians as it directly conflicted with informal verbal feedback that students provided to librarians and UHP coordinators after the library sessions, in which they stated that they already knew how to access and identify scholarly sources.

Finally, the researchers were curious to know if students who attended the information literacy sessions received different comments than those who did not. This was a very informal investigation, as the researchers could not determine whether there were differences between the students who attended and those who did not attend, nor was the size of the population that did not attend sufficient to draw generalizable conclusions. After calculating the percentage of students who received comments in each area, the researchers found that students who did not attend appeared to be more likely to receive comments about missing in-text citations and attributing claims, but were actually less likely to receive comments about citation formatting errors (Figure 1). 


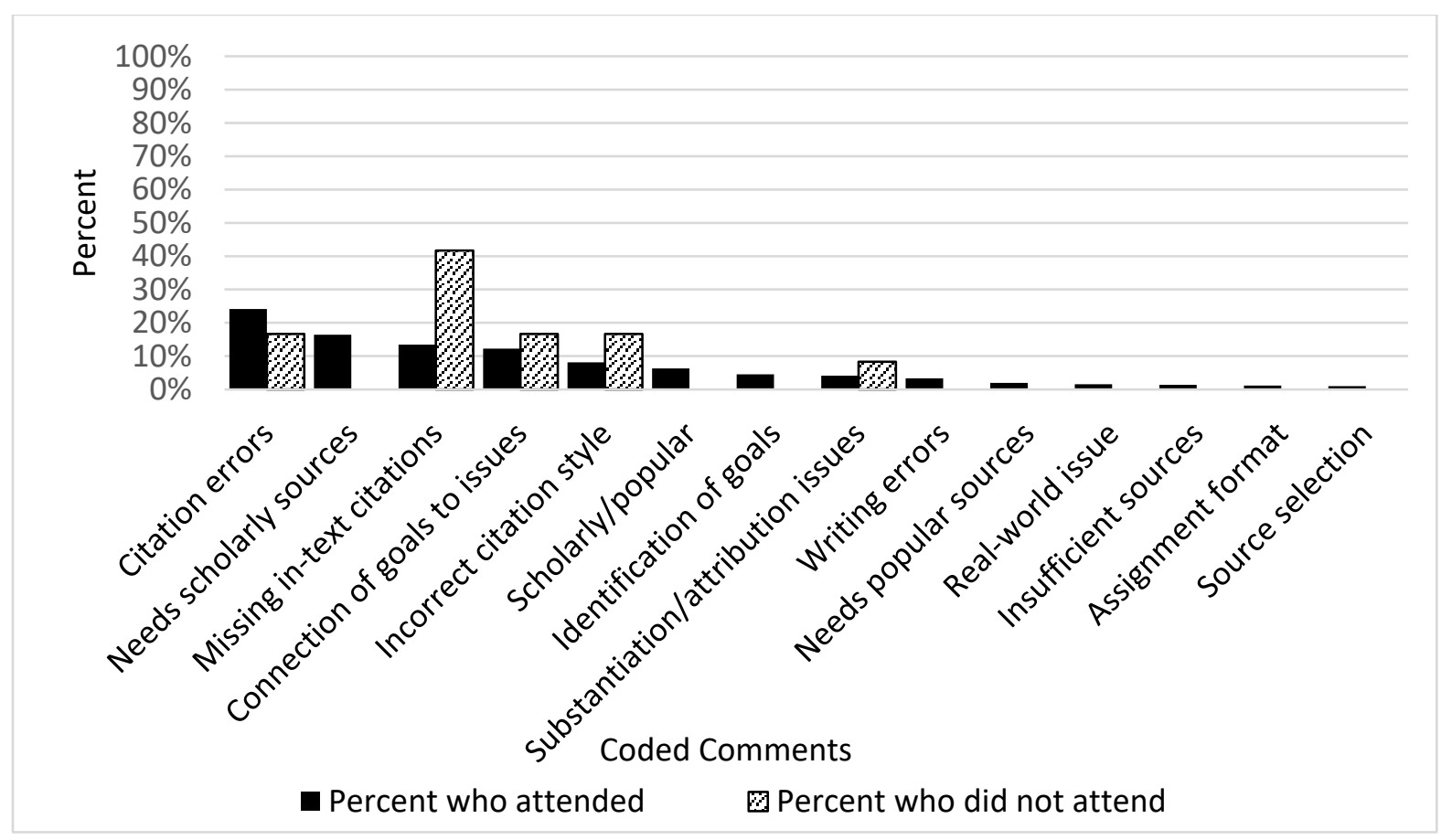

Figure 1: Coded Librarian Comments by Percentage (2015-2016)

\section{Re-Planning (2016-2017)}

The next step of the action research process was re-planning for the next cycle of implementation. Librarians and UHP coordinators met again ahead of the 2016-2017 academic year to discuss findings from the previous year and make preparations for the new academic year. In addition to formal assessment findings, librarians and instructors also considered anecdotal feedback from HHC students and from participating librarians when revising the lesson plan (Appendix C).

During the reflecting phase of the action research process, librarians identified citation formatting as the most common problem area in the 2015-2016 Bridge Essays. Previously, librarians had focused the citation part of the information literacy lesson plan on identifying correct elements of a citation. This choice was made because students were asked to use a citation format appropriate for their major, so there were a wide variety of possible correct citations. For the 2016-2017 Bridge Essay, librarians and UHP coordinators agreed that part of the lesson plan should focus on hands-on citation formatting activities.

Based upon the finding that students were struggling to correctly identify and use scholarly sources, librarians also decided to alter the information literacy lesson plan to spend more time talking about the nuances of what makes a source scholarly in different disciplines.

Finally, librarians recommended that the Bridge Essay format change from a formal essay format to an annotated bibliography format. During the feedback process, librarians saw that a number of students were experiencing issues synthesizing and properly attributing their sources. Because of the framework of the HHC course, which is zero-credit and sophomore-led, librarians believed that switching to an 
annotated bibliography format would help students focus their analyses on their sources and reduce attribution issues that could not be adequately handled in this course framework.

\section{Acting and Observing}

\section{Information Literacy Sessions}

After reflecting upon the demonstrated information literacy skills gaps from the previous cohort, librarians devised a new lesson plan for the 2016-2017 HHC information literacy sessions. As with the previous year, the lesson plan focused heavily on fundamental information literacy concepts such as source evaluation and citing sources. In this iteration, however, the lesson plan became less ambitious. Instead of focusing on five learning outcomes, librarians chose to focus on only three areas: evaluating scholarly sources, demonstrating basic database search strategies, and correcting incorrect citations.

The lesson plan intentionally increased the amount of time librarians spent on the citing of sources, as this was both an articulated goal from the HHC program and a clear problem area based upon the previous year's student data. The lesson plan also changed the way librarians taught citation. Previously, librarians were talking about citation in a conceptual way, which focused on helping students understand why scholars cite their sources and what information citations include. In 2016-2017, librarians shifted toward helping students with the mechanics of correcting formatting errors sometimes seen in computer-generated citations. Librarians created worksheets in several citation styles that contained citations with formatting errors, and asked students to work in groups to correct those citations. In addition to a change in focus on citation, librarians also increased the emphasis on source evaluation. Based upon their experience working with students the previous year, librarians believed that students were overconfident in their skill in evaluating sources. The 2016-2017 HHC library lesson plan required students to evaluate a variety of sources and discuss where they perceived those sources to fall on a continuum of scholarly and popular sources.

The information literacy sessions were delivered over the course of a week in November 2016. Librarians taught 19 separate information literacy sessions for 26 different HHC sections. As they had done the previous year, librarians combined sections when possible in order to maximize use of library spaces and librarian time. During these 19 library sessions, librarians taught 241 students. 41 students did not attend an information literacy session. In addition to the in-person library session, librarians made available to all students the same citation tutorial used in 2015-2016.

\section{Bridge Assignment Feedback}

In 2016-2017, the Bridge Essay was renamed the Bridge Assignment to reflect the shift from an essay to an annotated bibliography format. The 2016-2017 Bridge Assignment feedback process worked much the same way as the Bridge Essay feedback process from the previous year. Students turned their assignments in to HHC at the end of the winter break in January 2017. UHP coordinators shared the assignments with the First Year Experience Librarian, who replaced student names and identifiers with a unique code indicating the student's college and major. Thirteen librarians from five library departments volunteered to participate in a grading session on February 15 and 16, 2017. As with the previous year, 
the session began with a norming period, and then librarians began grading each assignment. Librarians evaluated using a rubric that had been revised from the previous year in response to feedback from UHP and from participating librarians who wanted to be more specific in their feedback. Using the revised rubric (Appendix D), two librarians would score each assignment independently. Where scores differed, a third librarian would score that category as well to break the tie. After all assignments were evaluated, rubrics and feedback were typed up and returned to students and also added to a spreadsheet for analysis.

Once all of the rubric sheets were added to the spreadsheet, one of the researchers reviewed the librarian comments. The researcher coded the comments into 15 categories (Table 2). As with the previous year, these categories were analyzed in relation to the topics covered in the information literacy sessions and by their frequency of appearance.

\begin{tabular}{|c|c|c|}
\hline Comment Categories & $\begin{array}{l}\text { Attended } \\
n=241\end{array}$ & $\begin{array}{l}\text { Did Not Attend } \\
n=41\end{array}$ \\
\hline Citation Errors & 143 & 24 \\
\hline Not an annotated bibliography & 61 & 2 \\
\hline Too many popular sources & 58 & 3 \\
\hline Needs scholarly sources & 56 & 3 \\
\hline Incorrect citation style & 54 & 10 \\
\hline Connection of goals to issues & 46 & 3 \\
\hline $\begin{array}{l}\text { Scholarly/popular (i.e. misidentification of } \\
\text { source type) }\end{array}$ & 39 & 5 \\
\hline Writing errors & 27 & 5 \\
\hline Missing in-text citations & 21 & 1 \\
\hline Substantiation/attribution issues & 19 & 2 \\
\hline Identification of goals & 12 & 2 \\
\hline Incomplete & 4 & 0 \\
\hline Real world issue & 3 & 2 \\
\hline Source selection (i.e. source quality issues) & 3 & 0 \\
\hline Insufficient sources & 2 & 1 \\
\hline
\end{tabular}

Table 2: Coded Librarian Comments (2016-2017) 


\section{Reflecting}

The 2016-2017 librarian comments provided another opportunity for librarians to better understand the impact of the library instruction sessions and students' information literacy skills and knowledge gaps. Analyzing this data revealed that, despite the library sessions' increased focus on formatting citations, "citation errors" was still the most common librarian comment category (Figure 2). Perhaps more promising, however, is the suggestion that students who attended the library session were less likely to make citation formatting errors than those who did not.

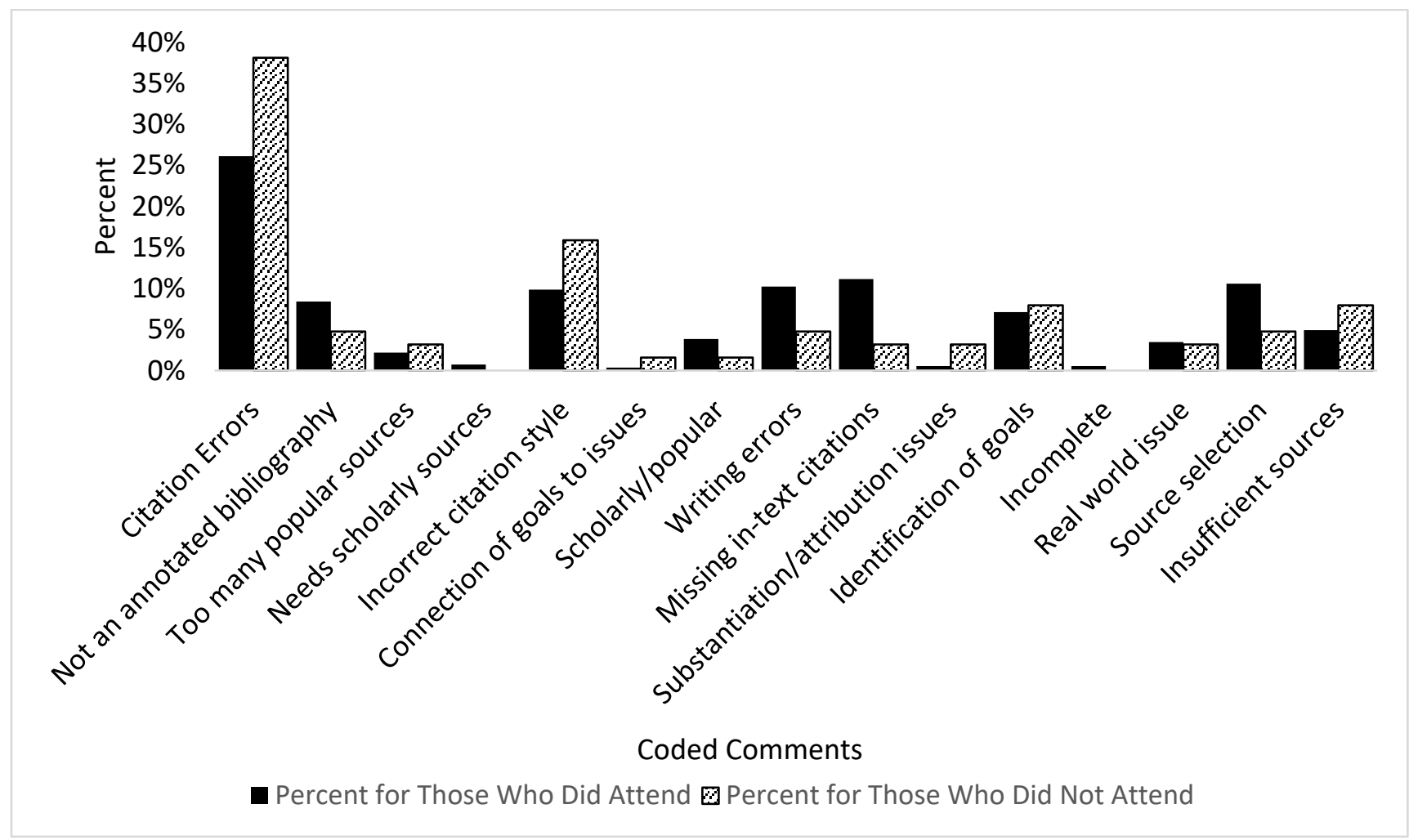

Figure 2: Coded Librarian Comments by Percentage (2016-2017)

Figure 2 also reveals that, while librarians still frequently commented on the need for students to include more scholarly sources in order to meet their assignment requirements, the percentage of comments that mentioned this issue dropped in 2016-2017. This decline may suggest that the hands-on source evaluation activity used in this year's library instruction session was more useful, though there is likely still room for improvement.

A third finding from the library feedback relates to the change in assignment format in 2016-2017. For the 2015-2016 cohort, one of the most common librarian comments was related to missing in-text citations, especially for students who did not attend the library sessions. It was based on this finding that librarians recommended an assignment format change. A new category was added in order to reflect a substantial number of comments related to students submitting assignments that did not match the annotated bibliography assignment criteria. A number of students submitted essays despite the shift to 
an annotated bibliography assignment format. Librarians and UHP coordinators believe that, because HHC sections are led by sophomores who took the class the previous year, some HHC students may have been guided by what their instructors did the previous year rather than what the revised assignment requirements dictated.

\section{Re-planning (2017-2018)}

Finally, librarians and UHP coordinators used their reflections from the 2016-2017 Bridge Assignment cycle to re-plan for the 2017-2018 academic year. Based upon student feedback in addition to the action research assessment, librarians and UHP coordinators decided to continue to revise both the information literacy sessions and the Bridge Assignment.

Based upon informal student feedback to librarians and UHP coordinators, students participating in the 2016-2017 cycle had a very positive response to the information literacy session citation formatting segment and suggested focusing the information literacy session even more heavily on that area. Because the assessment data revealed that citation formatting errors continued to be the most common librarian feedback, librarians agreed to make citation formatting the crux of the 2017-2018 library sessions. To facilitate both instruction and grading of citations, librarians requested that UHP coordinators revise the Bridge Assignment to require use of one of four citation styles: American Psychological Association (APA), Modern Language Association (MLA), Council of Science Editors (CSE), or Institute of Electrical and Electronics Engineers (IEEE). To support this revised Bridge Assignment, librarians also created new, more detailed citation tutorials.

Librarians also revised the HHC grading sessions for the 2017-2018 academic year. Although providing feedback from multiple librarians helped ensure consistency in feedback, it required an immense amount of librarian time and proved to be unsustainable on an annual basis. Instead, librarians decided to change the process so, after a norming period, each essay would be evaluated by a single librarian. This model reduced the amount of time needed to evaluate essays by more than half. Since the feedback provided was not associated with a grade, librarians felt that any inconsistency in feedback that remained after norming was acceptable.

\section{Discussion}

The action research method used for the UHP-library collaboration has proven to be an ideal fit for the iterative nature of library instruction and assessment. Each round of planning, acting, observing, and reflecting creates an opportunity for revision and improvement. Action research also facilitates communication and demonstration of value. As the researchers developed lesson plans, collected assessments, and analyzed data, they were able to share those results with stakeholders. The researchers developed infographics to share with UHP coordinators, offered informal presentations to subject librarians and library administrators, and shared the previous cohort's feedback with incoming groups of HHC students to explain curricular changes and why they were made. 
The action research method also provided invaluable insights into HHC students' information literacy skills and the value of information literacy interventions that librarians provided. Although HHC students consistently expressed confidence in their information literacy knowledge and skills, the quality of the Bridge Assignments remained uneven. Student motivation may be a factor in the quality issues, as students may not be motivated to put forth their full effort for an ungraded assignment for a zero-credit class. However, librarians and UHP staff have observed HHC students to be highly motivated and willing to put forth significant effort, even in an ungraded environment. Though motivation may be part of the issue, librarians theorize that many HHC students experience a gap between their familiarity with information literacy concepts and their ability to put them into practice.

One example of this gap was in the area of citations. Over the course of the project, the researchers learned that, regardless of their interventions, HHC students struggle with the mechanics of citing sources. While students often express confidence in their citing ability, this is often based on their familiarity with tools such as online citation generators and a misunderstanding of their accuracy. As the researchers were able to share data from the previous cohort, student overconfidence in their citation formatting abilities was reduced and students have provided informal feedback requesting additional time and focus on citation formatting in the information literacy session. While this suggests that the action research is helping to motivate student learning in this area, it is not yet bearing results in reduction of formatting errors.

This research has also shown that students are struggling in areas that are of immediate concern to librarians in addition to citation formatting. While citation formatting is an important aspect of the Bridge Assignment, many of the errors librarians comment about are due to misplaced commas, incorrect italicization, and inconsistent abbreviation, rather than major ethical violations. For this reason, librarians are reluctant to shift the focus of the information literacy session exclusively to citation formatting. One area that draws concern from librarians, though not from students, is source evaluation. For the Bridge Assignment, students are asked to find a minimum of three scholarly sources. Although, according to informal student feedback, many HHC students express confidence in their ability to find scholarly sources, many struggle. This has been one of the most common comments librarians are including in their feedback to students. Through this collaboration, librarians have seen students from a variety of disciplines struggle to identify the difference between a post on a university website and a research article or between a research article and an opinion piece in a peer-reviewed journal. To reduce this struggle, librarians want to provide additional support in source evaluation.

Another problem area that continues to cause concern for librarians is source attribution and substantiation. While issues related to missing in-text citations were largely resolved with the switch to an annotated bibliography format, librarians continued to note that a small but concerning number of students were making unsupported claims in their papers. Librarians had focused heavily on the mechanics of citing sources, but larger issues of supporting claims and attributing information to the proper source were not discussed in the library sessions. However, the mechanics of citation become irrelevant if students don't fully understand when and why they need to cite. While supporting claims may sometimes be considered within the purview of writing centers and composition instructors, the 
interwoven relationship between writing and research dictates that this is also within the purview of libraries.

Finally, this study confirms many of the challenges and benefits of using rubrics for assessment. Oakleaf (2009b) notes that the quality of rubric construction plays a major role in its effectiveness, and indeed, the researchers have found it necessary to make ongoing and iterative changes to the rubric in an effort to ease the evaluation process and improve results. Along with changes to the rubric's construction, the researchers have continued to work on the norming process. Though norming each year takes time and considerable discussion among librarians, it is a critical element to ensure that students are receiving comparable levels of feedback from librarians. Perhaps most significantly, the process of evaluating hundreds of HHC student essays each year is highly labor intensive. Completing the Bridge Assignment evaluations requires the time and expertise of a whole group of librarians who have a host of additional time commitments. Providing timely feedback to students is imperative, but necessitates an intensive effort on the part of librarians. Despite this major limitation, librarians continue to volunteer to participate. The Libraries/UHP collaboration provides librarians with a unique opportunity to examine the student learning artifacts of students from their disciplines and provide personalized feedback to students.

\section{Conclusion}

As the University Libraries' collaboration with HHC continues, the researchers continue to employ an action research model to implement, assess, and revise the information literacy lesson plan. Over the first two cycles of the project, it became apparent to researchers that, while student responses indicate that citation formatting is the information literacy skills gap that has become most apparent to them, the researchers believe that information literacy sessions need to continue to include instruction on key information literacy skills such as source evaluation and the conceptual basis of source attribution and claim substantiation. By continuing to assess and reflect on each cycle of the action research spiral, the researchers can continue to make iterative improvements to the HHC information literacy lesson plan and gauge the impact of those improvements on students' demonstrated information literacy skills. The researchers can also make the case for additional interventions, including supplementary tutorials, trainthe-trainer sessions, and pre/post assessment reflections. By implementing an action research approach to information literacy instruction and assessment, librarians can better understand their students' information literacy skills, improve their lesson plans, and communicate the impact of information literacy collaborations to stakeholders inside and outside the library.

\section{Bibliography}

Avery, S. (2017). Setting them up for success: Assessing a pre-research assignment for first-year international students. Communications in Information Literacy, 11(2), 324-338.

Carbery, A., \& Leahy, S. (2015). Evidence-based instruction: Assessing student work using rubrics and citation analysis to inform instructional design. Journal of Information Literacy, 9(1), 74-90. doi:10.11645/9.1.1980 
Erlinger, A. (2018). Outcomes assessment in undergraduate information literacy instruction: A systematic review. College \& Research Libraries, 79(4), 442-479. doi:10.5860/crl.79.4.442

Ferrer-Vinent, I. J., Bruehl, M., Pan, D., \& Jones, G. L. (2015). Introducing scientific literature to honors general chemistry students: Teaching information literacy and the nature of research to firstyear chemistry students. Journal of Chemical Education, 92(4), 617-624. doi:10.1021/ed500472v

Gariepy, L. W., Stout, J. A., \& Hodge, M. L. (2016). Using Rubrics to Assess Learning in Course-Integrated Library Instruction. Portal: Libraries and the Academy, 16(3), 491-509. doi:10.1353/pla.2016.0043

Harkins, M. J., Rodrigues, D. B., \& Orlov, S. (2011). "Where to start?": Considerations for faculty and librarians in delivering information literacy instruction for graduate students. Practical Academic Librarianship: The International Journal of the SLA, 1(1), 28-50.

Insua, G. M., Lantz, C., \& Armstrong, A. (2018). In their own words: Using first-year student research journals to guide information literacy instruction. portal: Libraries and the Academy, 18(1), 141161. doi:10.1353/pla.2018.0007

Johnson, A. M. (2012). Information literacy instruction for an honors program first-year orientation. Communications in Information Literacy, 6(2), 141-150.

Johnson, C. M., Anelli, C. M., Galbraith, B. J., \& Green, K. A. (2011). Information literacy instruction and assessment in an honors college science fundamentals course. College \& Research Libraries, 72(6), 533-547.

Kemmis, S., McTaggart, R., \& Nixon, R. (2014). The action research planner: Doing critical participatory action research. Springer Science \& Business Media.

Kiel, S., Burclaff, N., \& Johnson, C. (2015). Learning by doing: Developing a baseline information literacy assessment. portal: Libraries and the Academy, 15(4), 747-766.

Kraemer, E. W. (2007). Developing information literacy instruction for honors students at Oakland University: An information consulting approach. College \& Undergraduate Libraries, 14(3), 6373. doi:10.1300/J106v14n03_04

Margolin, S., Brown, M., \& Ward, S. (2018) Comics, questions, action! Engaging students and instruction librarians with the Comics-Questions Curriculum. Journal of Information Literacy, 12(2), pp.6075. http://dx.doi.org/10.11645/12.2.2467

Norton, L. S. (2009). Action research in teaching and learning: A practical guide to conducting pedagogical research in universities. London: Routledge. 
Oakleaf, M. (2008). Dangers and opportunities: A conceptual map of information literacy assessment approaches. portal: Libraries \& the Academy, 8(3), 233-253.

Oakleaf, M. (2009a). The information literacy instruction assessment cycle: A guide for increasing student learning and improving librarian instructional skills. Journal of Documentation, 65(4), 539-560. doi:10.1108/00220410910970249

Oakleaf, M. (2009b). Using rubrics to assess information literacy: An examination of methodology and interrater reliability. Journal of the American Society for Information Science and Technology, 60(5), 969-983. doi:10.1002/asi.21030

Robison M. (2017). Connecting information literacy instruction with transfer student success. Reference Services Review, 45(3):511-526. doi:10.1108/RSR-10-2016-0065.

Squibb, S. D., \& Mikkelsen, S. (2016). Assessing the value of course-embedded information literacy on student learning and achievement. College \& Research Libraries, 77(2), 164-183. doi:10.5860/crl.77.2.164

Wilson, M. C., \& Mulcahy, K. (1987). To better the best and brightest undergraduates. College \& Research Libraries News, 48(11), 700.

Yee, S. G. (1984, March). The role of the academic library in a university honors program. Paper presented at the annual meeting of the Michigan Academy of Arts, Science, and Letters, Big Rapids, MI. 


\section{Appendix A: 2015-2016 Lesson Plan}

\begin{tabular}{|c|c|c|c|c|}
\hline ACRL Framework & $\begin{array}{c}\text { Learning Objective/ } \\
\text { Outcome }\end{array}$ & $\begin{array}{c}\text { How Learning Will be } \\
\text { Assessed }\end{array}$ & $\begin{array}{c}\text { Teaching/ Learning } \\
\text { Activity }\end{array}$ & $\begin{array}{l}\text { Technology } \\
\text { Resources }\end{array}$ \\
\hline $\begin{array}{l}\text { Authority is } \\
\text { Constructed and } \\
\text { Contextual }\end{array}$ & $\begin{array}{l}\text { At the end of this } \\
\text { session, students will } \\
\text { be able to: } \\
\text { 1) Identify } \\
\text { characteristics of a } \\
\text { scholarly article } \\
\text { 2) Apply the } 5 \mathrm{Ws} \\
\text { and H model to } \\
\text { identify and } \\
\text { articulate strengths } \\
\text { and weaknesses in a } \\
\text { variety of web } \\
\text { content types }\end{array}$ & $\begin{array}{l}\text { 1) Group activity to } \\
\text { articulate scholarly } \\
\text { characteristics; } \\
\text { groups will identify at } \\
\text { least } 4 \text { characteristics } \\
\text { of a scholarly } \\
\text { resource } \\
\text { 2) Think/pair/share } \\
\text { activity; at least } 80 \% \\
\text { of class will correctly } \\
\text { identify } \\
\text { strengths/weaknesses }\end{array}$ & $\begin{array}{l}\text { 1) Lecture to } \\
\text { introduce topic, } \\
\text { followed by group } \\
\text { activity } \\
\text { 2) Lecture to } \\
\text { introduce topic, } \\
\text { followed by } \\
\text { think/pair/share } \\
\text { activity }\end{array}$ & $\begin{array}{l}\text { All students and } \\
\text { instructor must have } \\
\text { access to a } \\
\text { computer, internet, } \\
\text { and databases. } \\
\text { Instructor requires } \\
\text { projector. }\end{array}$ \\
\hline $\begin{array}{l}\text { Searching as } \\
\text { Strategic } \\
\text { Exploration }\end{array}$ & $\begin{array}{l}\text { At the end of this } \\
\text { session, students will } \\
\text { be able to: } \\
\text { 1) Articulate their } \\
\text { chosen topic in the } \\
\text { form of appropriate } \\
\text { search terms } \\
\text { 2) Find and select a } \\
\text { source on their } \\
\text { chosen topic }\end{array}$ & $\begin{array}{l}\text { 1) Students will write } \\
\text { down search terms on } \\
\text { a worksheet; at least } \\
80 \% \text { will have } \\
\text { appropriate search } \\
\text { terms } \\
\text { 2) Students will use } \\
\text { their search terms to } \\
\text { search a given } \\
\text { database and will } \\
\text { download at least one } \\
\text { article; at least } 80 \% \text { of } \\
\text { class will successfully } \\
\text { find an article }\end{array}$ & $\begin{array}{l}\text { 1) Interactive } \\
\text { lecture to introduce } \\
\text { topic, followed by } \\
\text { activity } \\
\text { 2) Instructor will } \\
\text { circulate and help } \\
\text { students } \\
\text { individually while } \\
\text { student search for } \\
\text { an article }\end{array}$ & $\begin{array}{l}\text { All students and } \\
\text { instructor must have } \\
\text { access to a } \\
\text { computer, internet, } \\
\text { and databases. } \\
\text { Instructor requires } \\
\text { projector. Instructor } \\
\text { will provide students } \\
\text { with a worksheet to } \\
\text { record search terms. }\end{array}$ \\
\hline $\begin{array}{l}\text { Information Has } \\
\text { Value }\end{array}$ & $\begin{array}{l}\text { At the end of this } \\
\text { session, students will } \\
\text { be able to: } \\
\text { Identify citation } \\
\text { information on a } \\
\text { given journal article. }\end{array}$ & $\begin{array}{l}\text { Instructor will use } \\
\text { PollEverywhere or } \\
\text { show of hands to ask } \\
\text { students to identify } \\
\text { citation information; at } \\
\text { least } 80 \% \text { will be able } \\
\text { to correctly identify } \\
\text { the elements of an } \\
\text { MLA or APA citation. }\end{array}$ & $\begin{array}{l}\text { Interactive lecture } \\
\text { to introduce topic, } \\
\text { followed by } \\
\text { PollEverywhere } \\
\text { quiz or show of } \\
\text { hands }\end{array}$ & $\begin{array}{l}\text { All students and } \\
\text { instructor must have } \\
\text { access to a } \\
\text { computer, internet, } \\
\text { and databases. } \\
\text { Instructor requires } \\
\text { projector. Instructor } \\
\text { requires } \\
\text { PollEverywhere for } \\
\text { assessment or will } \\
\text { use show of hands. }\end{array}$ \\
\hline
\end{tabular}




\section{Appendix B: 2015-2016 Rubric}

\begin{tabular}{|c|c|c|c|}
\hline & Acceptable & Needs Improvement & Score \\
\hline $\begin{array}{l}\text { Real-World } \\
\text { Issue }\end{array}$ & $\begin{array}{l}\text { Student has clearly } \\
\text { identified a real-world issue } \\
\text { in their field }\end{array}$ & $\begin{array}{l}\text { Paper is not focused on a real- } \\
\text { world issue }\end{array}$ & \\
\hline $\begin{array}{l}\text { Connecting } \\
\text { Goals to Issues }\end{array}$ & $\begin{array}{l}\text { Student articulates goal and } \\
\text { demonstrates why/how } \\
\text { goal addresses the issue in } \\
\text { their field }\end{array}$ & $\begin{array}{l}\text { Student does not articulates } \\
\text { goal and/or does not } \\
\text { demonstrate why/how goal } \\
\text { addresses the issue in their } \\
\text { field }\end{array}$ & \\
\hline Citation Style & $\begin{array}{l}\text { Citation style is appropriate } \\
\text { for the discipline and is at } \\
\text { least } 80 \% \text { correct }\end{array}$ & $\begin{array}{l}\text { Citation style is not } \\
\text { appropriate for discipline or is } \\
\text { less than } 80 \% \text { correct }\end{array}$ & \\
\hline $\begin{array}{l}\text { Number of } \\
\text { Sources }\end{array}$ & $\begin{array}{l}\text { Student has cited at least } 2 \\
\text { scholarly sources and } 1 \\
\text { popular source }\end{array}$ & $\begin{array}{l}\text { Student has not cited } 2 \\
\text { scholarly sources or has not } \\
\text { cited } 1 \text { popular source }\end{array}$ & \\
\hline \multicolumn{4}{|l|}{ Comments: } \\
\hline
\end{tabular}




\section{Appendix C: 2016-2017 Lesson Plan}

1. Introduction - who are you, why are they here

a. Tie to Honors Bridge Essay assignment - answer some of the issues that the last group had with this assignment

i. Relevant stats

b. This library session is to help them:

i. Recognize the difference between different types of sources

ii. Find different types of sources

iii. Cite those source correctly

2. Scholarly/popular activity (15 min)

a. Distribute Evaluating Sources matrix (also linked on LibGuide)

b. Six articles are linked on the guide

c. Work in small groups to evaluate each source

d. Discussion - share out what they found for each source, where they would put it (scholarly article/reputable popular source/not reputable source)

3. Search strategies (20 min)

a. Distribute Search Strategies worksheet

b. Demonstrate how to search in Discovery Layer

c. Give some time to search

4. Fix the citation (15 $\mathrm{min}$ )

a. Distribute Fix the Citation worksheet (give students an option to use the one most appropriate for them - refer to guide if not sure)

b. Give some time to work on the handout, refer to guide for citation manuals

i. Groups that gets the most correct gets candy

5. Conclusion

a. 1-minute paper for assessment (if there's time) 


\section{Appendix D: 2016-2017 Rubric}

\begin{tabular}{|c|c|c|c|}
\hline & Acceptable & Needs Improvement & Score \\
\hline $\begin{array}{l}\text { Real-World } \\
\text { Issue }\end{array}$ & $\begin{array}{l}\text { Student has clearly } \\
\text { identified a real-world issue } \\
\text { in their field }\end{array}$ & $\begin{array}{l}\text { Paper is not focused on a real- } \\
\text { world issue }\end{array}$ & \\
\hline Identifying Goal & Student articulates goal & $\begin{array}{l}\text { Student does not articulate } \\
\text { goal }\end{array}$ & \\
\hline $\begin{array}{l}\text { Connecting } \\
\text { Goal to Issues }\end{array}$ & $\begin{array}{l}\text { Student demonstrates } \\
\text { why/how goal addresses } \\
\text { the issue in their field }\end{array}$ & $\begin{array}{l}\text { Student does not demonstrate } \\
\text { why/how goal addresses the } \\
\text { issue in their field }\end{array}$ & \\
\hline $\begin{array}{l}\text { Appropriate } \\
\text { Citation Style }\end{array}$ & $\begin{array}{l}\text { Citation style is appropriate } \\
\text { for discipline }\end{array}$ & $\begin{array}{l}\text { Citation style is not } \\
\text { appropriate for discipline }\end{array}$ & \\
\hline $\begin{array}{l}\text { Citation } \\
\text { Formatting }\end{array}$ & $\begin{array}{l}\text { Citations are at least } 80 \% \\
\text { correct }\end{array}$ & $\begin{array}{l}\text { Citations are less than } 80 \% \\
\text { correct }\end{array}$ & \\
\hline $\begin{array}{l}\text { Number of } \\
\text { Sources }\end{array}$ & $\begin{array}{l}\text { Student has cited at least } \\
\text { five sources }\end{array}$ & $\begin{array}{l}\text { Student has not cited at least } \\
\text { five sources }\end{array}$ & \\
\hline $\begin{array}{l}\text { Scholarly } \\
\text { sources }\end{array}$ & $\begin{array}{l}\text { Student has cited at least } \\
\text { three scholarly sources }\end{array}$ & $\begin{array}{l}\text { Student has not cited at least } \\
\text { three scholarly sources }\end{array}$ & \\
\hline Popular sources & $\begin{array}{l}\text { Student has cited no more } \\
\text { than two popular sources } \\
\text { and popular sources are } \\
\text { credible in nature }\end{array}$ & $\begin{array}{l}\text { Student has cited more than } \\
\text { two popular sources and } \\
\text { popular sources are not } \\
\text { credible in nature }\end{array}$ & \\
\hline Readability & $\begin{array}{l}\text { Paper has no more than } \\
\text { moderate issues related to } \\
\text { readability }\end{array}$ & $\begin{array}{l}\text { Paper has major or substantial } \\
\text { issues related to readability }\end{array}$ & \\
\hline \multicolumn{4}{|l|}{ Comments: } \\
\hline
\end{tabular}

